\title{
Formation of Eco-friendly Silver Nanoparticle Microalgae using Chlorella vulgaris
}

\author{
Hermin Pancasakti Kusumaningrum ${ }^{1 *}$, Muhammad Zainuri2, Widianingsih2, \\ Wahyu Dewi Utari Haryanti ${ }^{2}$, Indras Marhaendrajaya ${ }^{3}$ and Robertus Triaji Mahendrajaya ${ }^{2}$
}

\author{
${ }^{1}$ Biotechnology Laboratory, Biology Department, Faculty of Sciences and Mathematics, Diponegoro University \\ ${ }^{2}$ Faculty of Fisheries and Marine Science, Diponegoro University \\ ${ }^{3}$ Faculty Sciences and Mathematics, Diponegoro University \\ Jl. Prof. Soedarto, SH Tembalang, Semarang, 50275, Indonesia \\ Email: herminsakti@gmail.com
}

\begin{abstract}
Biosynthesized silver nanoparticles (AgNPs) using organism have spurred great interest as a antimicrobial and biomedical agents. Green microalgae have advantages as they are easily available, grow rapidly and producing varieties metabolites. Synthesized of AgNPs from microalgae C. vulgaris offer environmentally antimicrobial agent. The objectives of the study is producing AgNPs microalgae using $C$. vulgaris as eco-friendly antimicrobial agent. The research methods was conducted by synthesizing silver nanoparticle microalgae using $C$. vulgaris following by characterization under UV-visible spectroscopy, transmission electron microscopy (TEM), and scanning electron microscope (SEM) and Energy-dispersive X-ray spectroscopy (EDX). The research result showed AgNPs C. vulgaris microalgae were produced with and without agitation treatment under different condition. The synthesized AgNPs C. vulgaris exhibited a maximum absorption at $312 \mathrm{~nm}$ and $398 \mathrm{~nm}$, and EDX analysis had determined that abundance chemical elements presented in a sample were carbon and silver. The TEM analysis revealed that they are spherical form. The spot of EDX analysis showed the presence of silver atoms. The SEM analysis shows the spherical shaped with some silver particle inside of the cell. These resut indicated that formation of silver nanoparticle microalgae using $C$. vulgaris has been succesfully obtained under the treatment.
\end{abstract}

Keywords: nanoparticle, silver, microalgae, TEM, SEM, C. vulgaris

\section{Introduction}

Recently, synthesis of silver nanoparticles using microorganisms, algae and plant extracts is already performed. The development of bionanotechnology in microalgae has shown that nano silver biosynthesis (nano silver) has increased the ability of microalgae as antimicrobial, antifungal and anticancer (Devi and Bimba, 2012; Rajesh et al., 2012; Sudha et al., 2013; Anuradha et al., 2014; Patel et al., 2015; Duong et al., 2016; El-Sheekh and El-Kassas, 2016; Rajeshkumar et al., 2012). Integration of microalgae with nano silver has wider the spectrum of antimicrobials capability in microalgae. This development also makes nano silver microalgae become an acceptable antimicrobial product because it is environmentally safe.

Nanobiotechnology dealing with metal nanoparticles and living organisms has spurred great interest due to its wide application range in almost every field of science and technology such as materials and manufacturing, nanoelectronics, information technology, medicine and health care, energy, biotechnology, food storage, household products, disinfectants, biomonitoring and environmental remediation (El-Nour et al., 2010; Balashanmugam and Kalaichelvan, 2015; Dahoumane et al., 2016). Eco-friendly nanoparticles have advantages especially in compatibility with pharmaceuticals over physical, chemical and microbial synthesis. High cost, inefficient treatment, contamination of toxic chemicals were leading to several effects when silver nanoparticles are being applied in the medical and pharmaceutical applications (Balashanmugam and Kalaichelvan, 2015; El-Sheekh and El-Kassas, 2016).

Chlorella is widely used as a health food and feed supplement, as well as in the pharmaceutical and cosmetics industries. C. vulgaris contains 17 amino acids of both essential amino acids and non essential essential amino acids. C. vulgaris also contains high levels of 34 lipid acid, Omega 3, Omega 6, Omega 9, AA, DHA and PUFA. Its carotenoid content is $\alpha$-carotene as much as 0.24 mg.g ${ }^{-1}$ and $\beta$-carotene as much as $0.86 \mathrm{mg}^{-1}$. 
(Merin et al., 2010; Sivakumar et al., 2011; Kusumaningrum and Zainuri, 2015). Although synthesis and characterization of silver nanoparticles on microalgae $C$. vulgaris had been conducted by Annamalai and Nallamuthu (2016), there are no reports concerning synthesis of AgNPs on $C$. vulgaris in higher concentration of silver using agitation treatment, their effect to the cell and how much concentration of silver in cell of microalgae.

\section{Materials and Methods}

\section{Microalgae material}

C. vulgaris microalgae were obtained from Brackishwater Aquaculture Development Centre (BBPBAP) on Jepara Indonesia. They were held in seawater tanks, recirculated and aerated, with the temperature set at $25-28^{\circ} \mathrm{C}$ and salinity at $30-32 \%$. The tanks were monitored daily. The microalgae were cultivated using sea water enriched with Walne media.

\section{Microalgae Media}

Walne media for microalgae C. vulgaris growth and cultivation consist of $\mathrm{NaH}_{2} \mathrm{PO}_{4} 20$ g.L $\mathrm{L}^{-1}$; NaNO3 10 g.L ${ }^{-1} ; \mathrm{FeCl}_{3} 0.15$ g.L ${ }^{-1} ; \mathrm{Na}_{2}$ EDTA 45 mg.L ${ }^{-1} ;{ }^{1} \mathrm{H}_{3} \mathrm{BO}_{3} 3.36$ g. $\mathrm{L}^{-1} ; \mathrm{MnCl}_{2} .4 \mathrm{H}_{2} \mathrm{O} 0.36$ g. $\mathrm{L}^{-1}$, trace metal solution $1 \mathrm{~mL} \cdot \mathrm{L}^{-1}$, and $1 \mathrm{~L}$ distilled water. Trace metal solution was consist of $\mathrm{NaMoO}_{4} .5 \mathrm{H}_{2} \mathrm{O} 0.39$ g.L ${ }^{-1} ; \mathrm{MnCl}_{2} .4 \mathrm{H}_{2} \mathrm{O} 1.81$ g.L ${ }^{-1}$; $\mathrm{H}_{3} \mathrm{BO}_{3} \quad 2.86$ g.L ${ }^{-1} ; \quad \mathrm{ZnSO}_{4} .7 \mathrm{H}_{2} \mathrm{O} \quad 0.222$ g.L $\mathrm{L}^{-1}$; $\mathrm{CuSO}_{4} .5 \mathrm{H}_{2} \mathrm{O} \quad 0.079$ g.L $\mathrm{L}^{-1} ; \mathrm{Co}\left(\mathrm{NO}_{3}\right)_{2} .6 \mathrm{H}_{2} \mathrm{O} \quad 0.0494$ g. $\mathrm{L}^{-1}$; $\mathrm{pH}$ was adjusted 6.8 . All of the trace metal ingredients were dissolved in $200 \mathrm{~mL}$ of distilled water. The solution was adjusting the $\mathrm{pH}$ to 7.6 with $\mathrm{HCl}$ or $\mathrm{NaOH}$ while boiled for 10 min, and bring it into 1 L. Solution sterilization was conducted by autoclaving at $120^{\circ} \mathrm{C}$ and $15 \mathrm{lb}^{-\mathrm{in}^{-2}}$ (103 kPa and). The medium for microalgae cultivation was using by adding $0.1 \mathrm{~mL}$ solution to each $10 \mathrm{~mL}$ of seawater (McVey and Moore, 1983; Bidwell and Spotte, 1985).

\section{Preparation of $2 \mathrm{mM}$ AgNO3 solution}

The solution of $2 \mathrm{mM} \mathrm{AgNO}_{3}$ was prepared by dissolving $1000 \mathrm{ppm} \mathrm{AgNO}_{3}$ with size about 1-10 $\mathrm{nm}$ in double distilled water and stored in amber coloured bottle to avoid auto oxidation of silver nitrate.

\section{Formation of microalgae silver nanoparticles}

Formation of microalgae silver nanoparticles was conducted using modification from some studies (Rajeshkumar et al., 2012; Sudha et al., 2013; Ibraheem et al., 2016). The $100 \mathrm{~mL}$ microalgae extract with total cell count $10^{-5}-10^{-7} \mathrm{~mL}$ 1 was added to $250 \mathrm{~mL} \mathrm{AgNO}_{3} 2 \mathrm{mM}$ solution, then the mixing solution was stirred for 6 hours using magnetic stirrer to perform agitation treatment on the sample (CVA). The same experiment was carried out with mixing solution without agitation treatment (CVWA). As a control, fresh C. vulgaris microalgae in Walne media and $\mathrm{AgNO}_{3}$ solution was used. The formation of silver nanoparticles was indicated by color change in solution from green to green brownish followed by brownish color.

\section{UV -Visible spectra analysis}

Synthesized silver nanoparticles were initially characterized by taking small aliquot of sample in to UV-Visible spectrophotometer absorption spectra at 300-700 nm using Shimadzu UV -1800 Spectrophotometer.

\section{SEM analysis of silver nanoparticles}

Scanning electron microscopic (SEM) analysis was carried by using Zeiss, EV-18 model. Samples of the dray material from aqueous solution of the silver nanoparticles (AgNPs) were prepared by centrifugation at 8,000 rpm for $5 \mathrm{~min}$. The pelet was dried. The SEM micrographs have been produced with magnifications 3000, 5000, 10000 and $20000 \mathrm{x}$ (diameters). SEMs are equipped with $x$ ray analytical capabilities. Thus topographic, cristallographic, and compositional information can be obtainaed rapidly, efficiently, and simultaneously from the same area.

\section{Energy-dispersive X-ray spectroscopy (EDS, EDX, EDXS, XEDS, EDXA or EDXMA)}

The X-ray excitation technique used for the elemental analysis or chemical characterization of a sample.

\section{Results and Discussion}

\section{UV-Visible spectra analysis}

Marine microalgae like C. vulgaris contain a number of biodynamic compounds of therapeutic value. These compounds provide valuable ideas for the development of new drugs against microbial infections and contamination (Kusumaningrum and Zainuri, 2014). The present study was conducted to use the marine microalgae, C. vulgaris for the synthesis of nanosilver microalgae. The microalgae extract may act as reducing and capping agents in silver nanoparticles biosynthesis. Reduction of silver ions into nanosilver microalgae during exposure of the $C$. vulgaris extracts could be followed by color change. Studies have indicated that biomolecules 
like protein, carbohydrates, lipids and phenols not only play a role in the capping of the nanoparticles, but also play an important role in reducing the ions to the nano size. The biomolecules found in these extracts like enzymes, vitamins, proteins, amino acids, and polysaccharides play a vital role in the reduction of $\mathrm{Ag}+$ ions. The addition of silver nitrate solution into microalgae solution will change the reaction mixture turning brown,due to the excitation of the surface plasma vibrations, indicated of the formation of silver nanoparticles.

Characterization of nanosilver microalgae were primarily performed by UV-Visible spectroscopy, which is proved to be a very useful technique for the analysis of these nanoparticles.

A single broad peak was observed for microalgae, control and treatment that was correlated to plasmon excitation of the nanosilver microalgae as illustrated on Figure 1. Another researcher was in agreement with this result, in founding that absorption of silver nanoparticle of $C$. vulgaris was about $400 \mathrm{~nm}$ (Annamalai and Nallamuthu, 2016); and also 400-450 $\mathrm{nm}$ for Chlorella and Scenedesmus (Patel et al., 2015)

The research based on the absorbance and wavelength values also show the synthesis of silver nanoparticles with agitation provide stability silver nanopartice of microalgae. The agitation accelerates the process of forming silver nanoparticles. The absorbance value increases with the increasing contact reaction time. As the microalgae suspension was mixed with the aqueous solution of the silver ion complex it was changed from green to brown colour. This is due to the excitation of the surface plasma vibrations, which indicates the formation of the nanosilver microalgae. UV-Visible Spectrograph of nanosilver microalgae has been recorded as a function of time by using quartz cuvette with distilled water as the reference.

Formation of the nanosilver microalgae of $C$. vulgaris monitored by UV-Vis spectroscopy exhibits a strong absorption due to the collective oscillation of the conduction electrons, after appropriate excitation by suitable radiation. This phenomenon is adressed as localized surface plasmon resonance, which is highly dependent on the size and shape of the nanoparticles.

\section{SEM analysis}

The SEM analysis showed morphological, cellular ultrastructural changes of $C$. vulgaris cells after 160 hours of exposure with AgNPs which also accomplished by the differences in surface topography as the electron beam sweeps across the specimen. As showed in Figure 2., the morphology of C. vulgaris cell with silver addition maintained a smooth exterior, a round and spherical shape with size 0,4-0,8 $\mu \mathrm{m}$ (CVA), 0,4-0,9 (CVWA), 0.91-1,43 $\mu \mathrm{m}(\mathrm{CV})$. Its also showed that agitation treatment did not caused greater effect on cell structure and morphologycaused by intense contact among AgNP particles and cells surface. This result was in contrast with another researcher which was proven that nanoparticles can caused change in morphology and dimensions of green algae Chlamydomonas reinhardtii and Dunaliella salina (Dahoumane et al., 2017). The AgNP microalgae also revealed spherical and cuboidal nanoparticles. Similar phenomenon was reported by Annamalai and Nallamuthu (2016) and Balashanmugam and Kalaichelvan (2015).

\section{EDX analysis}

Quantitative determination of bulk elemental composition and the location of AgNPs on cell surface for $C$. vulgaris as a control, AgNPs of $C$. vulgaris with agitation treatment and AgNPs of $C$. vulgaris without agitation treatment, were analyzed using the combination of both X-ray (EDX) and ZAF factor. Result shows that $C$. vulgaris and AgNPs microalgae contains four major basic elements of microalgae consist of Carbon (C), Oxygen(O), sodium $(\mathrm{Na})$, calsium $(\mathrm{Ca})$. EDX analysis for AgNPs of $C$. vulgaris shows the addition of two different elements $\mathrm{Cu}$ (Cuprum) and silver (Ag) as illustrated in Figure 3, 4, 5. Some other chemical compounds are also found in $\mathrm{AgNO}_{3}$ solution in very small quantities. Although $\mathrm{C}, \mathrm{O}$. Na, kalium (K), magnesium (Mg) and chloride $(\mathrm{Cl})$ was used as a standard concerning their based on their high concentration in the microalgae cell (Mandalam and Palsson, 1998). The EDX analysis also showed the high concentration of $\mathrm{Ag}$ indicating the formation of microalgae nano particle. Characteristic peaks was supported the

Table 1. UV-Visible absorption spectrum of microalgae and control

\begin{tabular}{lc}
\hline Microalgae & UV-Visible absorption spectrum \\
\hline $\mathrm{AgNO}_{3}$ & $343 \mathrm{~nm}$ \\
C. vulgaris & $410 \mathrm{~nm}$ \\
Nanosilver C. vulgaris with agitation & $312 \mathrm{~nm}$ \\
Nanosilver C. vulgaris without agitation & $398 \mathrm{~nm}$ \\
\hline
\end{tabular}




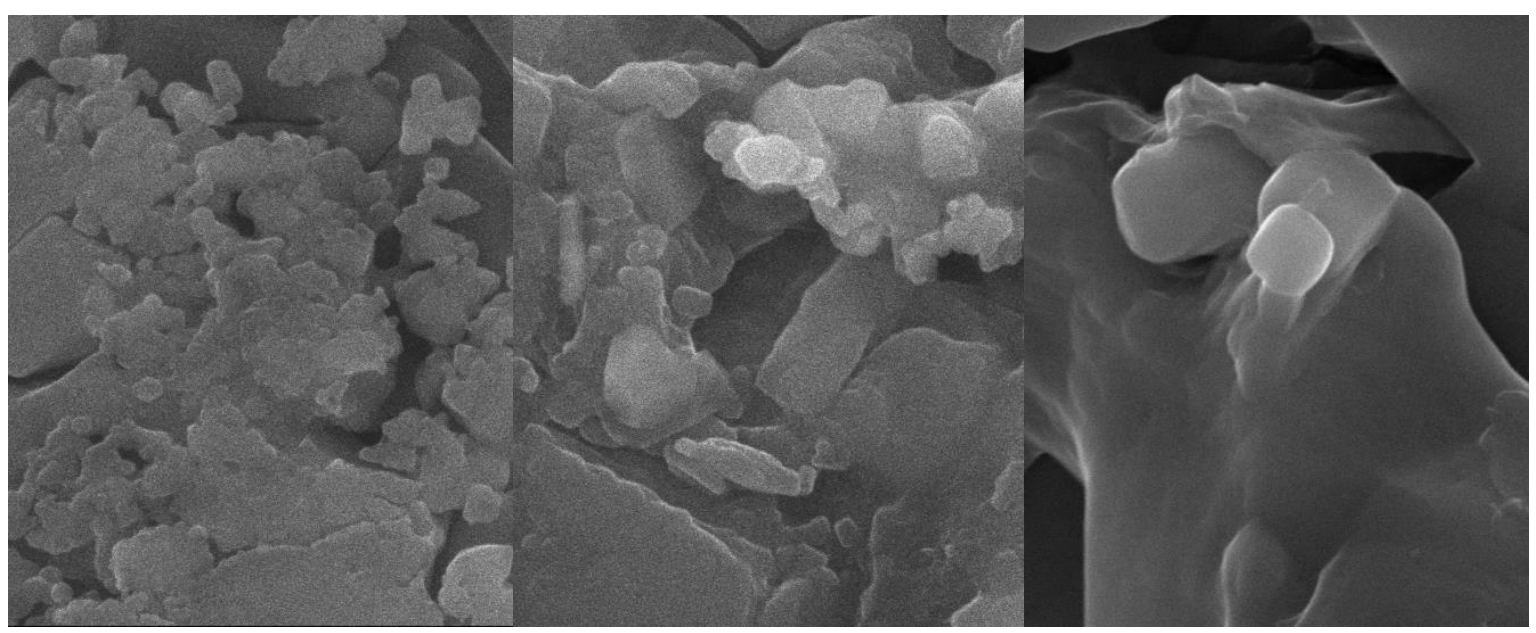

Figure 2. SEM image of nanosilver microalgae formed by C. vulgaris (left to right= nanosilver microalgae C.vulgaris without agitation CVA, nanosilver microalgae C.vulgaris with agitation, C.vulgaris) $(\times 20.000 \mu \mathrm{m})$

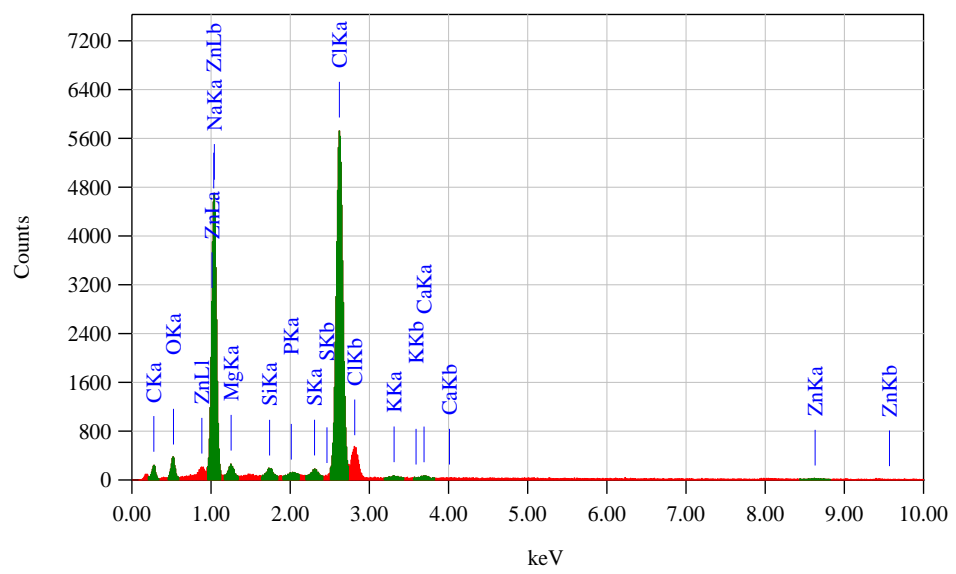

ZAF Method Standardless Quantitative Analysis (Oxide) Fitting Coefficient : 0.0181 Total Oxide : 24.0

\begin{tabular}{|c|c|c|c|c|c|c|c|c|}
\hline $\begin{array}{l}\text { Element } \\
\mathrm{C} K \\
\mathrm{O}\end{array}$ & $\begin{array}{l}(\mathrm{keV}) \\
0.277\end{array}$ & $\begin{array}{r}\text { Mass\% } \\
37.78 \\
9.82\end{array}$ & $\begin{array}{r}\text { Sigma } \\
0.14\end{array}$ & $\begin{array}{r}\text { Mol\% } \\
70.05\end{array}$ & $\begin{array}{l}\text { Compound } \\
\text { C }\end{array}$ & $\begin{array}{l}\text { Mass\% } \\
37.78\end{array}$ & $\begin{array}{r}\text { Cation } \\
0.00\end{array}$ & $\begin{array}{r}K \\
4.6763\end{array}$ \\
\hline $\mathrm{Na} K$ & 1.041 & 21.39 & 0.12 & 10.36 & $\mathrm{Na} 2 \mathrm{O}$ & 28.83 & 36.36 & 35.4530 \\
\hline $\mathrm{Mg} \mathrm{K}$ & 1.253 & 0.90 & 0.04 & 0.82 & $\mathrm{MgO}$ & 1.49 & 1.45 & 0.8598 \\
\hline $\mathrm{Si} K$ & 1.739 & 0.53 & 0.04 & 0.42 & $\mathrm{SiO} 2$ & 1.13 & 0.74 & 0.7708 \\
\hline $\mathrm{P} K$ & 2.013 & 0.17 & 0.04 & 0.06 & P2O5 & 0.39 & 0.22 & 0.2717 \\
\hline $\mathrm{S} K$ & 2.307 & 0.48 & 0.03 & 0.33 & $\mathrm{SO} 3$ & 1.19 & 0.58 & 0.8480 \\
\hline $\mathrm{Cl} \mathrm{K}$ & 2.621 & 28.03 & 0.07 & 17.61 & $\mathrm{Cl}$ & 28.03 & 0.00 & 55.667 \\
\hline K K & 3.312 & 0.19 & 0.02 & 0.05 & K2O & 0.23 & 0.19 & 0.292 \\
\hline $\mathrm{Ca} \mathrm{K}$ & 3.690 & 0.24 & 0.02 & 0.14 & $\mathrm{CaO}$ & 0.34 & 0.24 & 0.406 \\
\hline $\mathrm{Zn} \mathrm{K}$ & 8.630 & 0.47 & 0.06 & 0.16 & $\mathrm{ZnO}$ & 0.59 & 0.28 & 0.754 \\
\hline Total & & 100.00 & & 100.00 & & 100.00 & 40.05 & \\
\hline
\end{tabular}

Figure 3. The quantitative determination of bulk elemental composition of C. vulgaris

result in representing the dominant material in the cell of microalgae. These result were in agreement with Bhowmick et al. (2009). The use of EDX and ZAF Factor for AgNPs of $C$. vulgaris analysis is proven to be representative method for showing the elemental composition as supporting by previous result (Newbury and Ritchie, 2013; Trincavelli et al., 2014; Wassilkowska et al., 2015)

The EDX analysis was performed for the confirmation of $C$. vulgaris silver nanoparticles. Figure 3 shows the evidence of EDX analysis in the 


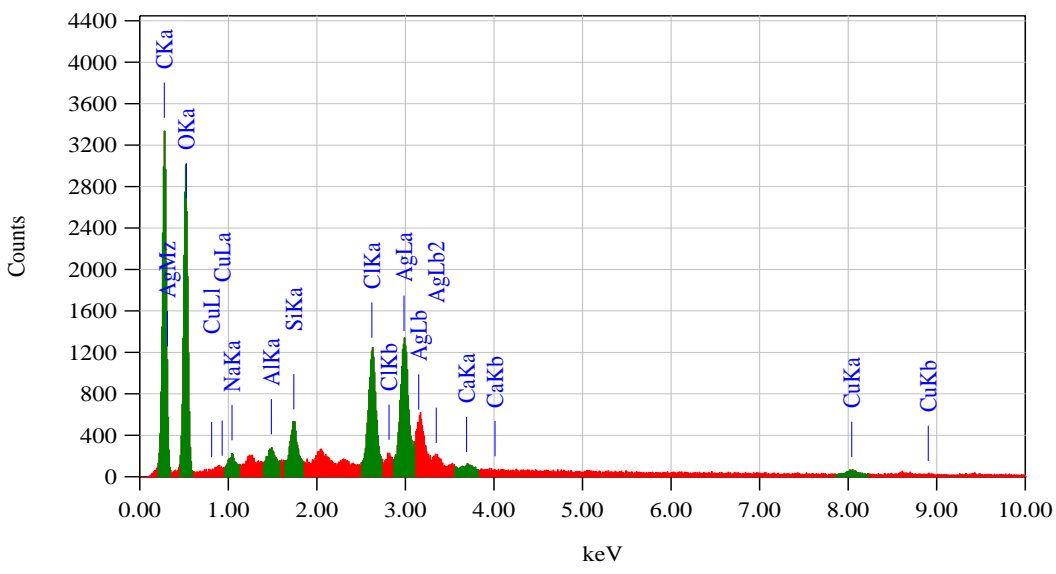

ZAF Method Standardless Quantitative Analysis(Oxide) Fitting Coefficient : 0.0444

Total Oxide : 24.0

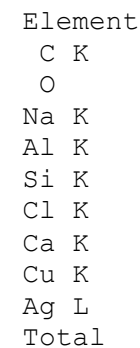

$\begin{array}{lr}(\mathrm{keV}) & \text { Mass\% } \\ 0.277 & 75.39 \\ & 3.26 \\ 1.041 & 0.54 \\ 1.486 & 0.40 \\ 1.739 & 1.14 \\ 2.621 & 3.84 \\ 3.690 & 0.21 \\ 8.040 & 1.17 \\ 2.983 & 14.05 \\ & 100.00\end{array}$

$\begin{array}{rrl}\text { Sigma } & \text { Mol\% } & \text { Compoun } \\ 0.05 & 96.07 & \mathrm{C} \\ 0.03 & 0.18 & \mathrm{Na} 2 \mathrm{O} \\ 0.03 & 0.11 & \mathrm{Al203} \\ 0.05 & 0.62 & \mathrm{SiO} 2 \\ 0.03 & 1.66 & \mathrm{Cl} \\ 0.02 & 0.08 & \mathrm{CaO} \\ 0.06 & 0.28 & \mathrm{CuO} \\ 0.09 & 1.00 & \mathrm{Ag} 2 \mathrm{O} \\ & 100.00 & \end{array}$

$\begin{array}{rrr}\text { Mass\% } & \text { Cation } & \text { K } \\ 75.39 & 0.00 & 61.7291 \\ & & \\ 0.73 & 2.76 & 0.7218 \\ 0.75 & 1.73 & 0.5568 \\ 2.45 & 4.80 & 1.9172 \\ 3.84 & 0.00 & 8.4684 \\ 0.29 & 0.60 & 0.3692 \\ 1.46 & 2.16 & 1.9397 \\ 15.10 & 15.34 & 24.2979 \\ 100.00 & 27.39 & \end{array}$

Figure 4. The quantitative determination of bulk elemental composition on AgNPs of $C$. vulgaris with agitation treatment

spot profile mode for each treatment. The EDX analysis combined with SEM was used also to characterize the chemical composition and the location of AgNPs on cell surface (Anuradha et al., 2014). The chemical composition of $\mathrm{AgNO}_{3}$ as illustrated the EDX analysis on Figure 3 was containing 31,9 \% concentration of Ag characterized by the high peak appearance in the XRD image as marked by green colour. The sharp diffraction patterns of the XRD spectra indicates a pure crystalline silver structure. The X-rays of $C$. vulgaris are scattered by diffraction owing to the unique crystalline structure of the material analyzed. This result was in agreement with previous study that the silver metals attached to the cell wall (Patel et al., 2015). Energy Dispersive Analysis of X-ray (EDAX) gives qualitative as well as quantitative status of elements that may be involved in the formation of AgNPs.

\section{TEM analysis}

The TEM analysis had showed the detailed information of the three-dimensional structure of silver nanopartice of microalgae from planar serial sections. Figure 6 showed the construction of the microalgae cell image from a through-focal series of images formed in a scanning confocal optical microscop. Its also exhibited the silver crystal that entering into the cell that was not cause the disruption of cell wall or making lysis of the cell. This result also exhibited that the silver metals not only attached to the cell wall but also embedded in the cell. This analytical method also proven the characterization of the particle structure and confirm the presence of the nanoparticles. Silver ions released from AgNPs may penetrate inside the cell membranes interacting with sulfur and phosphorus containing compounds such as proteins and DNA (Jyoti et al., 2016).

The study showed that production of microalgae silver nanoparticle using $C$. vulgaris can be performed under the concentration of $2 \mathrm{mM}$ of silver under agitation treatment. This result was in contrast with other researcher in having the lysis of the cell in $1 \mathrm{mM}$ of silver concentration Annamalai and Nallamuthu (2016). This study also exhibited that the cell still maintaining their structure stability while containing about $32 \%$ of the silver. This result showing the indication that agitation treatment was supporting the stability of the cell in dispersing the silver material around the cell.

These data showed implication that silver nanoparticle microalgae can be potentially saved for 


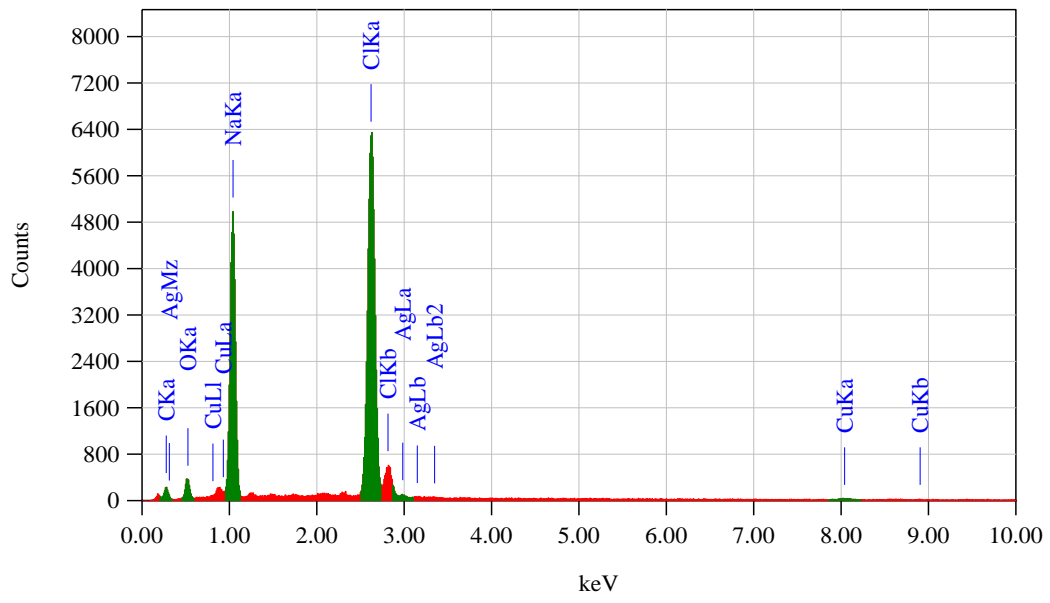

\begin{tabular}{|c|c|c|c|c|c|c|c|c|}
\hline & \multicolumn{7}{|c|}{ Total Oxide : 24.0} & \multirow{3}{*}{$\begin{array}{r}K \\
3.8099\end{array}$} \\
\hline \multirow{2}{*}{$\begin{array}{l}\text { Element } \\
\mathrm{C} \mathrm{K} \\
\mathrm{O}\end{array}$} & $(\mathrm{keV})$ & Mass응 & Sigma & Mol\% & Compound & Mass응 & Cation & \\
\hline & 0.277 & $\begin{array}{r}35.43 \\
8.49\end{array}$ & 0.14 & 67.80 & $\mathrm{C}$ & 35.43 & 0.00 & \\
\hline $\mathrm{Na} \mathrm{K}$ & 1.041 & 23.67 & 0.10 & 11.83 & $\mathrm{Na} 2 \mathrm{O}$ & 31.91 & 46.54 & 36.5197 \\
\hline $\mathrm{Cl} \mathrm{K}$ & 2.621 & 30.84 & 0.07 & 19.99 & $\mathrm{Cl}$ & 30.84 & 0.00 & 57.5180 \\
\hline $\mathrm{Cu} \mathrm{K}$ & 8.040 & 0.80 & 0.06 & 0.29 & $\mathrm{CuO}$ & 1.00 & 0.57 & 1.1952 \\
\hline Ag L & 2.983 & 0.77 & 0.05 & 0.08 & Ag20 & 0.82 & 0.32 & 0.9571 \\
\hline Total & & 100.00 & & 100.00 & & 100.00 & 47.43 & \\
\hline
\end{tabular}

Figure 5. The quantitative determination of bulk elemental composition on $\mathrm{C}$. vulgaris without agitation treatment
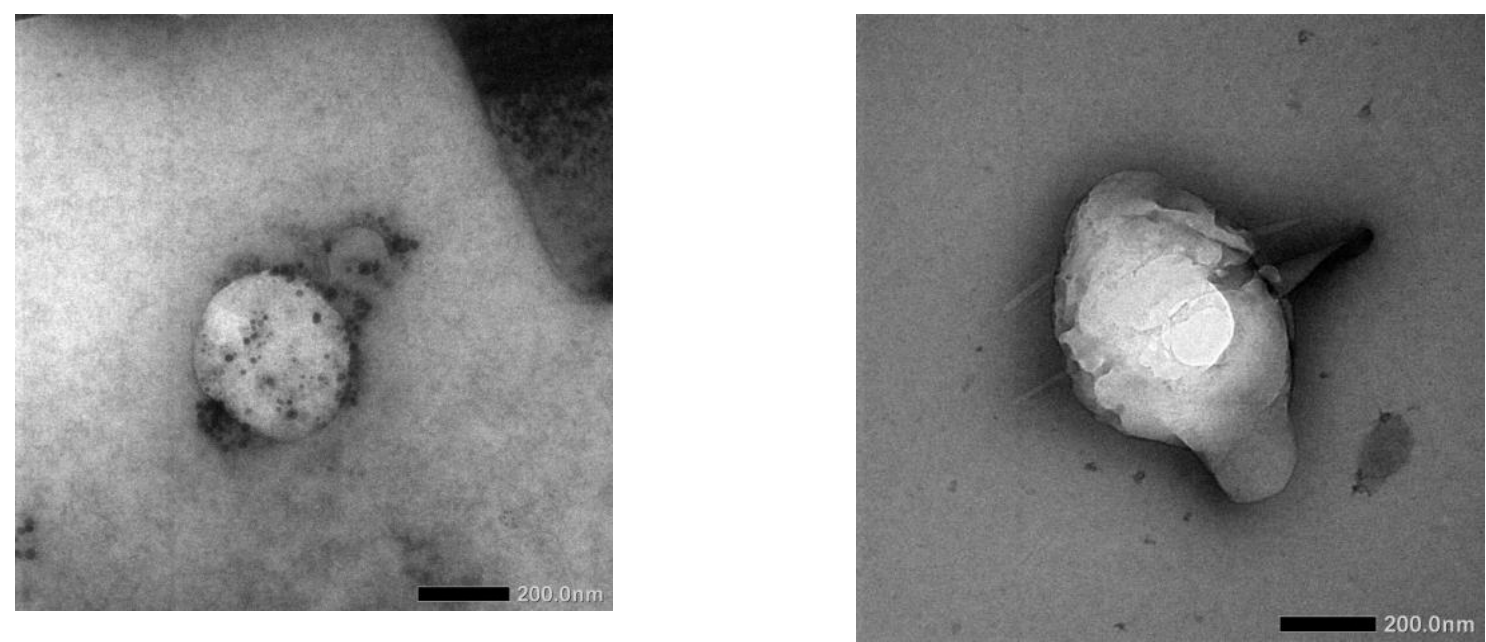

Figure 6. TEM analysis of AgNPs of $C$. vulgaris cell with agitation (left) and without agitation (right) $(200 \mathrm{~nm})$

application on human body at low concentrations, capable for large scale production because of fast multiplication of cells, and environmentally safe, comparing with chemical and physical methods as in agreement with previous research (El-Sheek and ElKassas, 2016, Ibraheem et al., 2016). Interestingly, the use of microalgae as organic coating material shown by this study has opened up opportunities for the development of this potency in future studies especially for biomedical applications.

\section{Conclusion}

The present study reveals that the microalga C. vulgaris is good source for the synthesis of silver nanoparticles at a high silver concentration. The 
formation of silver nanoparticles was confirmed by characterization using UV-Vis, SEM, EDX and TEM techniques. The microalgae silver nanoparticles formed were quite stable in the solution. The agitation treatment act as the surface active stabilizing molecules and cell structure for the synthesis of silver nanoparticles.

\section{Acknowledgments}

The authors gratefully thank to Directorate of Research and Public Services (Dirlitabmas), Indonesian Ministry of Research, technology and Higher Education according to Letter of Assigment of Hibah PUPT, Number: 344-43/UN7.5.1/PP/2017 date 5 May 2017 in funding this research.

\section{References}

Annamalai, J. \& Nallamuthu, T. 2016. Green synthesis of silver nanoparticles: characterization and determination of antibacterial potency. Appl. Nanosci. 6(2): 259-265

Anuradha, G., Syama Sundar B., Sreekanth kumar J., \& Ramana, M.V. 2014. Synthesis and Characterization of Silver Nanoparticles from Ocimum basilicum L. var.thyrsiflorum. Eur. J Acad. Essays 1(5): 5-9

Balashanmugam, P. \& Kalaichelvan, P.T. 2015. Biosynthesis characterization of silver nanoparticles using Cassia roxburghii DC. aqueous extract, and coated on cotton cloth for effective antibacterial activity. Int. J. Nanomedicine. (Suppl 1: Challenges in biomaterials research) 10: 87-97

Bidwell, J.P. \& Spotte, S. 1985. Artificial Sea Water: Formulas and Methods. Boston, Massachusetts: Jones and Bartlett Publisher. 349 p.

Bhowmick, T.K., Suresh, A.K., Kane, S.G., Joshi, A.C., \& Bellare, J.R. 2009. Physicochemical characterization of an Indian traditional medicine, Jasada Bhasma: detection of nanoparti cles containing non-stoichiometric zinc oxide. J. Nanopart. Res. 11: 655-664. doi: 10.1007/s11051-008-9414-z

Dahoumane, S.A., Mechouet, M., Alvarez, F.J., Agathos, S.N. \& Jeffryes, C., 2016. Microalgae: An outstanding tool in nanotechnology. Bionatura. 1(4): 196-201. doi: 10.21931/RB/ 2016.01.04.7
Devi, J.S. \& Bhimba, B.V. 2012. Anticancer Activity of Silver Nanoparticles Synthesized by the Seaweed Ulva lactuca Invitro. 1: 242. doi:10.4172/scientificreports.242

Duong, T.T., Le, T.S., Tran, T.T.H., Nguyen, T.K., Ho, C.T., Dao, T.H., Le, T.P.Q., Nguyen, H.C., Dang, D.K., Le, T.T.H. \& Ha, P.T. 2016. Inhibition effect of engineered silver nanoparticles to bloom forming cyanobacteria. Adv. in Nat. Sci. Nanosci. Nanotechnol. 7(3): 035018.

El-Nour, K.M.A., Eftaiha, A.A., Al-Warthan, A. and Ammar, R.A. 2010. Synthesis and applications of silver nanoparticles. Arabian J. Chem. 3(3):135-140.

El-Sheekh, M.M. \& El-Kassas, H.Y. 2016. Algal production of nano-silver and gold: Their antimicrobial and cytotoxic activities: A review. J. Gen. Eng. Biotechnol. 14(2): 299-310

Ibraheem, I.B.M., Abd-Elaziz, B.E.E., Saad, W.F., \& Fathy, W.A., 2016. Green biosynthesis of silver nanoparticles using marine Red Algae Acanthophora specifera and its antimicrobial activity. J. Nanomed. Nanotechnol. 7: 409. doi: 10.4172/2157-7439.1000409

Jyoti, K., Baunthiyal, M. \& Singh, A. 2016. Characterization of silver nanoparticles synthesized using Urtica dioica Linn. leaves and their synergistic effects with antibiotics. J. Radiation Res. Appl. Sci. 9(1): 217-227. doi: 10.1016/j.jrras.2015.10.002

Kusumaningrum, H.P. \& Zainuri, M. 2014. Optimization and stability of total pigments production of fusan from protoplast fusion of microalgae Dunaliella and Chlorella in vivo: Attempts on production of sustainable aquaculture natural food. Int. J. Mar. Aqua. Res. Conserv. Co-existence. 1(1): 1-5.

Kusumaningrum H.P. \& Zainuri M. 2015. Detection of bacteria and fungi associated with Penaeus monodon postlarvae mortality. In: International Conference on Tropical and Coastal Region EcoDevelopment 2014 (ICTCRED). Hadiyanto H, Heru S \& Ocky KR. eds Proc. Env. Sc. 23: 329337

Mandalam, R.K. \& Palsson, B.O. 1998. Elemental Balancing of Biomass and Medium Composition Enhances Growth Capacity in High-Density Chlorella vulgaris Cultures Biotechnol. Bioeng. 59(5):605-611

McVey, J.P. \& Moore, J.R. 1983. Algal food cultures at the centre oceanologique du pacifique. In 
Handbook of Mariculture: Crustacean Aquaculture, $2^{\text {nd }}$ ed., Vol. 1 McVey, JP. ed. CRC Press, Boca Raton, p: 43-69

Merin, D.D., Prakash, S. \& Bhimba, B.V. 2010. Antibacterial screening of silver nanoparticles synthesized by marine micro algae. Asian Pacific J. Trop. Med. 3(10): 797-799. doi: 10.1016/ S1995-7645(10)60191-5

Newbury, D.E. \& Ritchie, N.W.M. 2013. Is Scanning Electron Microscopy/Energy Dispersive X-ray Spectrometry (SEM/EDS) Quantitative ?. Scanning, 35: 141-168

Patel, V., Berthold, D., Puranik, P. \& Gantar, M. 2015. Screening of cyanobacteria and microalgae for their ability to synthesize silver nanoparticles with antibacterial activity. Biotech Report. 5: 112-119. doi : 10.1016/j.btre.2014. 12.001

Rajesh, S., Raja, D.P., Rathi, J.M. \& Sahayaraj, K. 2012. Biosynthesis of $\mathrm{Ag}$ nanoparticles using Ulva fasciata (Delile) ethyl acetate extract and its activity against Xanthomonas campestris pv. Malvacearum. J. Biopest, 5: 119-128
Rajeshkumar, S., Kannan, C. \& Annadurai, G., 2012. Green synthesis of silver nanoparticles using marine brown algae Turbinaria conoides and its antibacterial activity. Int. J. Pharma and Bio Sci., 3(4): 502-510.

Sivakumar, N., Sundararaman, M. \& Selvakumar, G. 2011. Efficacy of micro algae and cyanobacteria as a live feed for juveniles of shrimp Penaeus monodon. Afr. J. Biotechnol. 10(55): 11594-11599

Sudha, S.S., Rajamanickam, K. \& Rengaramanujam J., 2013. Microalgae mediated synthesis of silver nanoparticles and their antibacterial activity against pathogenic bacteria. Indian $\mathrm{J}$. Exp. Bio. 52: 393-399

Trincavelli J., Limandri S. \& Bonetto R. 2014. Standardless quantification methods in electron probe microanalysis, Review. Spectrochim. Acta Part B 101: 76-85

Wassilkowska A., Czaplicka-Kotas A., Zielina M. \& Bielski A. 2015. An analysis of the elemental composition of micro-samples using eds technique. Technical Transactions Chem. 13318 